\title{
How Some Lawyers Prioritise Earnings and Not Necessarily the Best Interests of Their Clients
}

\author{
Renier Steyn \\ Graduate School of Business Leadership, University of South Africa \\ PO Box 392, Unisa, 0003, South Africa
}

Tel: 27-116-520-254Ｅ-mail: steynr@unisa.ac.za

Received: April 12, $2021 \quad$ Accepted: May 3, $2021 \quad$ Published: May 7, 2021

doi:10.5296/csbm.v8i1.18615 URL: https://doi.org/10.5296/csbm.v8i1.18615

\begin{abstract}
This case deals with an employee seeking justice in a labour dispute and who ends up paying a small fortune in legal fees and still fails to find satisfaction. The case provides food for thought for human resource practitioners and particularly lawyers regarding under the circumstances when they should be ethically bound to advise disgruntled employees to cease pursuing a grievance that has little prospect of success. How and when should the human resource practitioner provide professional and independent advice, and when should the ethical (sic) lawyer refuse to approach the courts with a case containing insufficient merit?
\end{abstract}

Keywords: Ethics, Labour disputes, Human resource practitioner, Legal representation, Constructive dismissal, Whistle blower

\section{Introduction}

It is often alleged that money buys justice, and that the more money you spend, the better the quality of that justice will be. In South Africa, from the perspective of the ordinary citizen, this bias is even more relevant, given the fact that half of the population hovers on the breadline, thus leaving many people deprived of justice.

When it comes to labour disputes, the regular employee is also at a disadvantage, if the case moves beyond the Commission for Conciliation, Mediation and Arbitration (CCMA). Experience has shown that government departments and big corporate organisations are more than willing to use mighty legal teams to appeal rulings against them and to escalate grievances to higher courts. The aggrieved employee seldom has the means to endure the lengthy process, or to match their employer's legal power. This is a David and Goliath 
situation, with the small employee pitted against the gigantic employer. Here the professionality of the human resource practitioners comes to the foreground, appropriately serving their employer, but also the employee.

This case deals, however, not so much with aforementioned disparities, but rather with the ethics of legal teams. Legal teams, whether representing the employer or the employee, seem more than willing to "take instructions from their clients" and play the legal battle game indefinitely, or at least as long as the money keeps rolling in. This is because South African lawyers very seldom get paid on a contingency basis, which implies the payment of a percentage of the money received if the case is won. Instead, they receive payment for time worked. This means that the more time they spend on a matter, the more they get paid. It could be argued that if a lawyer is unethical or incompetent and unnecessarily drags on a case with little merit he/she will be rewarded with more money. Simply stated, attorneys and advocates are paid for the time they allegedly spend on matters, and the more time it takes to settle matters, the more money they earn. Legal teams often tell a client what he/she want to hear, whilst knowing well that the claim has little chance of being upheld by the courts. Lawyers "take instructions from their clients" which are often not in the best interest of said clients and they gain monetary reward for inefficiency, all the while lobbying for delays (for the purposes of further investigation) and extended court dates.

This case is about the lone individual taking on a state institution who has to resort to using private savings, pension money and loans, to claim what she feels is ethically and rightfully due to her. Spare a thought for this middle-class individual who does not have the resources to play the legal game forever, but desperately wants to see justice done. The state, and those individuals aligned to government institutions, can - and often do - manipulate the judicial system in order to delay justice for their own benefit, knowing that the average citizen or employee will not win a delayed war, simply because they do not have the financial resources to do so. Obtaining legal assistance is an expensive, often unaffordable undertaking for the ordinary middle-class person.

\section{The Case}

Take the case of Tanja Zulu (Note 1) (51). She worked for the Information Technology Group (ITG) for 24 years and 7 months. She was employed as a vetting officer in the Security Vetting Department of a state-owned entity, conducting security checks on individuals responsible for the South African government's IT systems. Her task was to vet prospective and current IT employees, to prevent possible extortion, sabotage, blackmail, or any acts that might endanger IT security in the South African government agencies. Prospective employees' bank statements, qualifications and references are routinely checked during this process. Personal and reference interviews are conducted and reports are then compiled on the findings.

Tanja reported to the manager of the Vetting Department, a certain A.D. Jones. She had become increasingly worried about the inaccurate information received by the department's vetting officers responsible for the pre-employment vetting. She addressed these concerns with Jones in 2014, and again in 2017. Bank statements were outdated, and documentation 
was often incomplete. A colleague was found to be borrowing money from prospective employees, another colleague faked an interview with a prospective employee, and a third person in the team continued to make obvious mistakes, whilst being protected by Jones. Some employees posed as commissioners of oaths, although they were not licensed to do so. Jones became annoyed by Tanja's complaints. He started involving the human resource department and pressurised Tanja to either lodge a grievance, or to be charged with misconduct instead. According to him, the workplace was not "a democracy". He lowered the scores on her performance score card and denied her access to the internal pre-vetting system, which provides access to the work done by vetting employees. She was therefore denied the proper means to perform her job.

After much agonising, Tanja made a terse disclosure on 28 July 2017 in terms of the ITG whistle blowing policy and the Protected Disclosures Act 26 of 2000. She was convinced that top security clearances were being exchanged for favours. ITG responded by moving her to the Risk Management Department. The Internal Audit team was then called upon to investigate the matter. It found that her allegations lacked substance. ITG proceeded to schedule a disciplinary hearing for 14 September 2017, which incidentally happened to be her birthday. Tanja was charged with "conduct detrimental to the maintenance of good order within the workplace", as well as contravention of company policy, namely the ITG whistle blowing policy. Before the disciplinary hearing, she was told that a polygraph test would be performed. The idea was to use the polygraph results during the disciplinary hearing. The polygraph outcome was shown to her and it reported that she had been mostly "untruthful" during the procedure. She was consequently advised by management to resign. She also found out that the whole vetting team had been coerced into testifying against her. By now profoundly humiliated and upset, Tanja felt that she had no other choice but to resign, a decision which she announced in a WhatsApp message to Jones the day before the internal hearing, and again at the start of the disciplinary hearing.

Tanja then proceeded to take her employer to the Commission for Conciliation, Mediation and Arbitration (CCMA), claiming that her resignation was in fact a case of constructive dismissal (Note 2)3, as her working conditions had become intolerable. The CCMA constitutes a route set up to deal with labour disputes, providing justice at a reasonable or no cost. Lawyers are generally not allowed to represent complainants in these hearings. It can of course be risky for a lay person to enter the process without receiving legal assistance beforehand. Tanja therefore employed a particular law firm to advise her. At the CCMA hearing she learned that the CCMA does not have the necessary jurisdiction to automatically handle unfair dismissal disputes and they directed her to refer the matter to the Labour Court instead. Tanja's lawyers obviously advised her incorrectly, but were still willing to take R19 152 for their professional (sic) advice.

The trial was set to commerce on 16 April 2019 and was scheduled to last for 3 days. Arriving at court and ready to proceed, the legal team argued that the days set for the court hearing were not sufficient and that Tanja needed 5 days to present her case at court. This occurred despite the fact that the legal team itself had proposed the number of days to the court in the first place. As a result of this demand, her case was postponed until a next 
available court date. At this stage Tanja obviously started to suspect that the legal team was not acting in her best interests. To compound matters, the attorneys charged Tanja a further R171 431 for services rendered, which included the services of an advocate.

Convinced of the merits of her case, and not satisfied with the services of her attorneys, she was able to find another law firm willing to take her case to the Labour Court. The now unemployed Tanja immersed herself in the case with the team of lawyers and was eager to have her day in court. The new law firm booked for four days in court. Tanja and her lawyers felt that the hearing went quite well. However, Judge M.T. Baloyi of the Labour Court dismissed her case in February 2020. Tanja's star witness during the trial was Gert Du Toit, a highly experienced polygraph expert with the South African Police Service (SAPS). He had gone through her ITG polygraph test results and found these to be unreliable, and his review did not support the original examiner's conclusion that she had been deceptive regarding the issue under investigation. The examination was not conducted in accordance with the professional standards for polygraph practitioners and could therefore not be used in a valid manner to discredit her character. However, Judge Baloyi rejected this evidence as "irrelevant" to the case. Tanja felt that these negative polygraph reports would ruin her professional reputation, but the evidence obtained by Du Toit was simply disregarded.

During the whole process, Jones and his cronies at ITG continued to make use of taxpayers' money to employ a legal team. Tanja, on the other hand, had to pay approximately R366 759 out of her own pocket to the second law firm to fund the Labour Court exercise. The said law firm never considered that the polygraph test could be deemed irrelevant, nor did they advise their client that she may not have a strong case to pursue.

Tanja still felt aggrieved, and with the assistance of the same law firm made application for the right to appeal the case. Judge Baloyi refused her the right to appeal the decision of the Labour Court. Now financially overinvested in a case she still strongly believed in, she decided to petition the decision. For this step legal aid was required yet again, and the law firm was more than willing to assist her in the matter. She is currently awaiting the outcome of the petition. The estimation of these petition costs is around R108 891(Note 3), and counting.

Listening to Tanja's story, questions inevitably arise about the ethical conduct of legal teams, who are often eager to take a prospective client's money, but incapable of producing the desired results. Without delving too deeply into the legal and technical issues surrounding this case, it is submitted that lawyers should properly assess cases and inform their clients honestly what their chances of success in court will be. The lawyers in this particular case should have known that employees who resign prior to a disciplinary enquiry will seldom succeed in proving that they were constructively dismissed (see for example Billion Group v Ntshangase (2018) 39 ILJ 2516 (LC)). Given the repeated failures of Tanja's legal teams to convince the court, would it not be justified to question either their knowledge of the subject matter, or their ethics, or maybe both aspects? 


\section{Some Questions}

Arcane legal terminology and procedures can easily leave an individual bewildered, placing mere mortals in the hands of legal professionals. The question which begs answering is how accountable (and ethical) should legal teams be? Any of us will be outraged if a plumber does not fix the problem he was asked to look at and still charges an exorbitant fee. Why then the exaggerated respect and reverence for the legal profession? Does their ability to master legal jargon and techniques really justify the fees they often charge without necessarily delivering a positive outcome? The lack of results can be devastating for someone like Tanja, desperate for justice and intent on clearing her name, so that she can move on with her life. Equating the repair of a blocked toilet to intricate legal proceedings may of course seem simplistic, but is it not high time that we start asking probing questions to the men and women in black robes regarding their personal accountability? Surely the quality of the service received should correlate to the hard-earned money spent by clients?

\section{Moving on}

In Tanja's case, she was at times frustrated by the mediocre quality of work from her legal representatives, which often forced her to fend for herself in court. She was also disgruntled by sloppy billing from her teams. Regular double billing for services not delivered was received.

In an attempt to make sense of the legal world that she has been exposed to over the past four years, Tanja educated herself and has since completed a postgraduate diploma in Advanced Labour Law. She has also completed her first year towards a LLB degree.

In the meantime, she has to grapple with the fact that she has already spent a total of R666 233 on this case and is still waiting for justice to be served, knowing well that her former government employer is in a far more advantageous position to continue the legal battle. There are no guarantees that she will eventually find a favourable outcome from the South African legal system, but she can rest assured that it is almost certain that she will have no difficulty finding another lawyer eager and willing to assist her in court.

\section{Reflections}

Did Tanja have any case to present at the Labour Court?

Do you think Judge Baloyi was correct to deem the polygraph evidence as "irrelevant"?

How and when should human resource practitioners provide professional and independent advice to disgruntled employees?

How and when should ethical (sic) lawyers refuse to take instructions from their clients?

What are the odds of a positive outcome of the petition Tanja launched? And why?

\section{References}

Billion Group v Ntshangase (2018) 39 ILJ 2516 (LC)). Retrieved from http://www.saflii.org/za/cases/ZALCJHB/2018/211.html 
Grogan. J. (2020). Workplace law (13th ed.). Cape Town, Juta.

Labour Relations Act. (1995). Labour Relations Act 66 of 1995. Retrieved from https://www.gov.za/documents/labour-relations-act

Society for Human Resource Management. (2021). Code of Ethical and Professional Standards in Human Resource Management. Retrieved from https://www.shrm.org/about-shrm/pages/code-of-ethics.aspx

South African Board for People Practices. (2021). SABPP code of conduct. Retrieved from https://www.sabpp.co.za/resource/resmgr/website_files_1/code_of_conduct_2017_sabpp_p.p df

\section{Notes}

Note 1. Pseudonyms are used as to protect the anonymity of those who were involved in the case.

Note 2. In all dismissal cases the employee must prove the dismissal. Once the employee has proved that he or she was dismissed, the onus is on the employer to prove that the dismissal was both procedurally and substantively fair (see Section 192 of the Labour Relations Act 66 of 1995). In claiming constructive dismissal employees must prove that they were subject to coercion, duress or undue influence (Grogan, 2020). In terms of section 187(h) of the Labour Relations Act 66 of 1995 a dismissal is automatically unfair if the dismissal is "a contravention of the Protected Disclosures Act, 2000, by the employer, on account of an employee having made a protected disclosure defined in that Act." Therefore it appears that the Applicant in this matter (Tania) must have alleged during the CCMA proceedings that the reason for her dismissal was that she had made a protected disclosure in terms of the Protected Disclosures Act 26 of 2000. The CCMA lacks jurisdiction to hear matters regarding automatic unfair dismissals. Only the Labour Court has jurisdiction to hear such matters.

Note 3. This amount is likely be around R45 000, as it seems that the same item was billed twice.

\section{Copyrights}

Copyright for this article is retained by the author(s), with first publication rights granted to the journal.

This is an open-access article distributed under the terms and conditions of the Creative Commons Attribution license (http://creativecommons.org/licenses/by/4.0/). 